\title{
PENGARUH UKURAN PERUSAHAAN, UKURAN DEWAN KOMISARIS DAN SENSITIVITAS INDUSTRI TERHADAP PENGUNGKAPAN CORPORATE SOCIA RESPONSIBILITY PADA PERUSAHAAN LQ-45 YANG TERDAFTAR DI BEI TAHUN 2014-2016
}

\author{
Yunina $^{1}$, Neny Eftiana ${ }^{2}$ \\ ${ }^{1,2}$ Prodi Akuntansi Fakultas Ekonomi dan Bisnis Universitas Malikussaleh Lhokseumawe \\ yunina@unimal.ac.id
}

\begin{abstract}
This study aims to determine the effect of the size of the company, size of the board of commissioners and industrial sensitivity to the disclosure of corporate social responsibility partially and simultaneously. The data of this study were taken from 87 observations. The number of samples used in this study was 29 LQ-45 companies listed on the IDX in 2014-2016. The samples were taken by using purposive sampling technique. The method of data analysis used in this study was multiple linear regression analysis. The result of the research showed that size of company significantly influenced the disclosure of corporate social responsibility with significance level by 0,021, while size of board of commissioners did not significantly influence the disclosure of corporate social responsibility with the value of significance by 0,621 , but industry sensitivity has significant influence to corporate social responsibility disclosure with a significant value of 0,010. The simultaneous test showed that firm size, board size and industry sensitivity simultaneously and significantly influenced the disclosure of corporate social responsibility significantly by 0,004. The GMS members who have the authority to propose, appoint and dismiss the board of commissioners should consider the candidates of the board of commissioners to be proposed, and the further research should expand the object of research and develop other factors that can affect the disclosure of corporate social responsibility such as foreign ownership, growth company, good corporate governance $(G C G)$ practices and several other factors.
\end{abstract}

Keywords: Disclosure of Corporate Social Responsibility, GRI, Size of Company, Size Board of Commissioner, Industrial Sensitivity. 


\section{PENDAHULUAN}

Permasalahan-permasalahan sosial yang dihadapi oleh perusahaan di Indonesia terjadi karena lemahnya penegakan peraturan tentang tanggung jawab sosial perusahaan, misalnya tentang aturan ketenagakerjaan, pencemaran lingkungan, perimbangan bagi hasil suatu industri dalam era otonomi daerah (Putra, 2011). Praktik CSR di Indonesia telah mendapat perhatian yang cukup besar, hal ini latarbelakangi oleh berbagai kasus yang terjadi. Tragedi lingkungan dan sosial juga terjadi di Indonesia seperti kasus limbah tekstil di Kecamatan Rancaekek yang disebabkan oleh operasi perusahaan tekstil PT Insan Sandang Internusa, Kasus Tambang G Resources yang di protes warga Batang Toru karena limbah operasi perusahaan merusak lingkungan dan ekosistem sekitar, PT. Freeport di Irian Jaya menunjukkan tidak adanya tanggungjawab perusahaan terhadap aktivitasnya (Radyati, 2008).

Oleh berbagai kasus yang terjadi, timbul tuntutan serta harapan masyarakat mengenai peran perusahaan dalam masyarakat. Salah satu munculnya tuntutan masyarakat dikarenakan terjadi kerusakan lingkungan di berbagai daerah, maka dari itu lahirlah konsep Corporate Social Responsibility (CSR). Tanggung jawab sosial atau yang dikenal dengan corporate social responsibility adalah mekanisme bagi suatu organisasi untuk secara sukarela mengintegrasikan perhatian terhadap lingkungan dan sosial ke dalam operasinya dan interaksinya dengan stakeholder, yang melebihi tanggung jawab organisasi di bidang hukum (Anggraini, 2006). Perusahaan dalam melakukan pengungkapan corporate social responsibility belum ada standar mengenai seberapa banyak tanggung jawab sosial yang harus diungkap. Saat ini seluruh perusahaan berbagai sektor bisnis di Indonesia sebagian besar mengklaim bahwa perusahaan mereka telah melaksanakan kewajiban sosialnya terhadap lingkungan sekitar perusahaan, oleh karena itu, sebagian besar perusahaan tersebut melakukan pengungkapan Corporate Sosial Responsibility sebagai motivasi untuk meningkatkan kepercayaaan publik terhadap pencapaian usaha perbaikan terhadap lingkungan sekitar perusahaan. Seluruh perusahaan di Indonesia semakin dituntut untuk memberikan informasi yang transparan atas aktivitas sosialnya, sehingga pengungkapan terhadap corporate social responsibility diperlukan peran dari akuntansi pertanggungjawaban sosial (Anggraini, 2006).

Pada tahun 2007, pemerintah mengambil tindakan dengan mengesahkan Undang-Undang RI No.40 Tahun 2007 Tentang Perseroan Terbatas dengan memasukan peraturan mengenai kewajiban setiap entitas bisnis untuk melaksanakan maupun mengungkapkan tanggung jawab sosial dan lingkungan yang tertuang didalam Bab V Pasal 74 dan Pasal 66 ayat (2) bagian C. Undang-Undang Perseroan Terbatas No.40 Tahun 2007 Bab V Pasal 74 ayat 1 menetapkan bahwa perseroan memiliki kewajiban melaksanakan tanggung jawab sosial dan lingkungan, baik dari perseroan yang menjalankan kegiatan usahanya bergerak di bidang dan/atau berkaitan dengan sumber daya alam. Pelaksanaan tanggung jawab sosial dapat berupa perbaikan terhadap lingkungan masyarakat sekitar perusahaan. Ayat 2 dan 3 menegaskan bahwa tanggung jawab sosial dan lingkungan yang telah dianggarkan dan diperhitungkan sebagai biaya perseroan yang pelaksanaannya dilakukan dengan memperhatikan kepatutan dan kewajaran. Apabila perseroan tidak melaksanakan kewajiban tersebut akan mendapatkan sanksi yang tegas sesuai dengan ketentuan peraturan perundang-undangan berlaku. Adapun sanksi-sanksi yang diterapkan seperti peringatan tertulis, pembatasan kegiatan usaha, pembekuan kegiatan dan/atau fasilitas penanaman modal dan pencabutan kegiatan usaha dan/atau fasilitas penanaman modal. Sesuai dengan Pasal 66 ayat (2) bagian $\mathrm{C}$ menyebutkan bahwa perseroan terbatas selain menyampaikan laporan keuangan, tetapi juga diwajibkan melaporkan pelaksanaan tanggung jawab sosial dan lingkungan.

Pertanggungjawaban pengungkapan corporate social responsibility harus memberikan informasi yang relevan kepada publik sesuai dengan hasil pencapaian usaha perbaikan terhadap lingkungan sekitar perusahaan. Penyampaian informasi pengungkapan corporate social responsibility yang relevan kepada publik akan meningkatkan kepercayaan publik dan investor terhadap tanggung jawab sosial dan lingkungan yang telah dilaksanakan oleh seluruh perusahaan di Indonesia seperti yang diungkapkan dalam teori legitimasi yang menjelaskan bahwa praktik pengungkapan tanggung jawab perusahaan harus dilaksanakan sedemikian rupa agar aktivitas dan kinerja perusahaan dapat diterima oleh masyarakat. Guna melegitimasi aktivitas perusahaan di mata masyarakat, perusahaan cenderung menggunakan 
kinerja berbasis sosial dan pengungkapan informasi lingkungan. Selain pengungkapan berbasis sosial kegiatan perusahaan juga dapat menimbulkan dampak sosial dan lingkungan, sehingga praktik pengungkapan sosial dan lingkungan merupakan alat manajerial yang digunakan perusahaan untuk menghindari konflik sosial dan lingkungan.

Association of Chartered Certified Accountants (ACCA) menyatakan bahwa pertanggungjawaban sosial perusahaan diungkapkan di dalam laporan yang disebut Sustainability Reporting. Sustainability Reporting adalah pelaporan mengenai kebijakan ekonomi, lingkungan dan sosial, pengaruh dan kinerja organisasi dan produknya di dalam konteks pembangunan berkelanjutan (sustainable development). Sustainability Reporting meliputi pelaporan mengenai ekonomi, lingkungan dan pengaruh sosial terhadap kinerja organisasi. Sustainability report harus menjadi dokumen strategik yang berlevel tinggi yang menempatkan isu, tantangan dan peluang sustainability development yang membawanya menuju kepada core business dan sektor industrinya.

Banyak perusahaan yang semakin menyadari pentingnya CSR dalam menarik investor dan memuaskan stakeholder. diantaranya penelitian oleh Epstein dan Freedman (1994) dikutip dalam Nur (2012) berdasarkan survei yang telah dilakukan menemukan juga bahwa investor invidual cenderung lebih tertarik untuk berinvestasi pada perusahaan yang memasukkan aspek kegiatan sosial dalam laporan tahunannya. Hal ini sesuai dengan teori stakeholder yang menyatakan bahwa eksistensi perusahaan ditentukan oleh para stakeholder dimana pada akhirnya perusahaan akan memenuhi segala kebutuhan para stakeholder untuk mendapatkan dukungan seperti yang diharapkan oleh perusahaan.

Adapun dalam pelaksanaannya, corporate social responsibility dipengaruhi oleh beberapa faktor. Beberapa penelitian terdahulu menggunakan faktor yang berbeda-beda dalam setiap penelitiannya. Yuliana (2008) menggunakan faktor ukuran perusahaan, profitabilitas, tipe industri, ukuran dewan komisaris, dan konsentrasi kepemilikan dalam penelitiannya. Anggraini (2006) menggunakan faktor kepemilikan manajemen, financial leverage, ukuran perusahaan dan tipe industri, serta profitabilitas sebagai variabel independen dalam penelitiannya. Purwanto (2011) hanya menggunakan faktor tipe industri, ukuran perusahaan, dan profitabilitas dalam penelitiannya. Sedangkan Nur (2012) menggunakan faktor profitabilitas, ukuran perusahaan, kepemilikan saham, dewan komisaris, leverage dan pengungkapan media sebagai variabel independennya. Berbeda dengan penelitian Aulia (2015) yang menggunakan faktor ukuran perusahaan, profitabilitas, leverage, kinerja lingkungan dan liputan media sebagai variabel independennya dan environmental disclosure sebagai variabel dependennya. Dari berbagai faktor penelitian di atas, dalam penelitian ini digunakan faktor-faktor ukuran perusahaan, ukuran dewan komisaris dan sensitivitas industri dalam hubungannya dengan pengungkapan corporate social responsibility.

Salah satu variabel dalam penelitian ini adalah ukuran perusahaan. Perusahaan berskala besar cenderung akan lebih mudah melakukan pengungkapan tanggung jawab sosial karena perusahaan besar memperoleh hasil penjualan yang lebih tinggi dibandingkan dengan perusahaan berskala kecil (Sembiring, 2005). Di samping itu, perusahaan berskala kecil lebih berkonsentrasi kepada peningkatan hasil penjualan perusahaannya dibandingkan melakukan pengungkapan CSR. Penelitian yang dilakukan oleh Purwanto (2011), Fauzi et al. (2007) dan Djakman dan Machmud (2008) menunjukkan bahwa ukuran perusahaan berpengaruh signifikan terhadap pengungkapan CSR, akan tetapi berbeda dengan penelitian yang dilakukan oleh Rawi dan Muchlish (2010) yaitu yang menemukan bukti empiris bahwa total aktiva tidak berpengaruh signifikan terhadap pengungkapan pertanggungjawaban sosial.

Variabel lain yang mempengaruhi pengungkapan CSR adalah ukuran dewan komisaris (Sembiring 2005). Semakin besar jumlah anggota dewan komisaris, maka semakin mudah untuk mengendalikan CEO dan pengawasan yang dilakukan akan semakin efektif (Sembiring, 2005). Dikaitkan dengan pengungkapan tanggung jawab sosial perusahaan, maka tekanan terhadap manajemen juga akan semakin besar untuk mengungkapkannya. Penelitian yang pernah dilakukan Subiantoro (2015), Sembiring (2005), Sitepu dan Hasan (2009) telah meneliti hubungan ukuran dewan komisaris dengan pengungkapan CSR, hasilnya bahwa ukuran dewan komisaris berpengaruh secara signifikan terhadap pengungkapan CSR. Akan tetapi penelitian yang dilakukan oleh Arifin (2013) menunjukkan bahwa 
ukuran dewan komisaris tidak berpengaruh terhadap pengungkapan CSR.

Variabel berikutnya yang mempengaruhi pengungkapan CSR adalah sensitivitas industri yang diukur dengan tipe industri (Purwanto, 2011). Sensitivitas industri dapat diartikan sebagai seberapa besar pengaruh aktivitas industri yang bersinggungan langsung dengan lingkungan. Pada umumnya perusahaan dengan tingkat sensitivitas industri yang tinggi terhadap lingkungan akan memperoleh perhatian yang tinggi pula dari masyarakat karena aktivitas operasinya yang memiliki potensi mempengaruhi alam. Penelitian yang dilakukan Anggraini (2006) menggambarkan perusahaan yang memiliki tingkat sensitivitas industri tinggi akan memperoleh perhatian yang lebih dari masyarakat dan kepentingan lain karena aktivitas industri yang berpotensi mempengaruhi kepentingan luas, baik dari segi ekonomi, sosial dan lingkungan. Hasil penelitiannya menyatakan sensitivitas industri berpengaruh secara signifikan terhadap pengungkapan tanggung jawab sosial.

Pada penelitian ini, perusahaan LQ-45 yang dikategorikan sebagai high profile antara lain perusahaan perminyakan dan pertambangan lain, kimia, hutan, kertas, otomotif, penerbangan, agribisnis, tembakau dan rokok, produk makanan dan minuman, media dan komunikasi, energi (listrik), engineering, kesehatan serta transportasi dan pariwisata. Sedangkan kelompok industri low profile terdiri dari bangunan, keuangan dan perbankan, supplier peralatan medis, properti, retailer, tekstil dan produk tekstil, produk personal, dan produk rumah tangga (Purwanto 2011).

Pada penelitian ini akan dilakukan pengujian menggunakan perusahan LQ-45 yang listing di BEI tahun 2014-2016. Indek LQ-45 adalah perusahaan dengan likuiditas (liquid) tinggi, yang diseleksi oleh Bursa Efek Indonesia melalui beberapa kriteria pemilihan. Selain penilaian atas likuiditas, seleksi atas emiten-emiten tersebut juga mempertimbangkan kapitalisasi pasar. Bursa efek Indonesia secara rutin memantau perkembangan kinerja emiten-emiten yang masuk dalam penghitungan indeks LQ-45. Selain mempertimbangkan kriteria likuiditas dan kapitalisasi pasar, akan dilihat juga keadaan keuangan dan prospek pertumbuhan perusahaan berkelanjutan.

Untuk menggambarkan fenomena dalam penelitian ini dapat dilihat pada tabel 1 berikut ini mengenai pengungkapan corporate social responsibility pada perusahaan LQ-45 tahun 20142016. Nilai pengungkapan CSR diperoleh melalui cara content analysis menggunakan indeks CSR yang dikeluarkan oleh Global reporting index (GRI) sebagai acuan pengungkapan CSR yang baik. Berikut hasil pengungkapan CSR di perusahaan LQ-45 tahun 2014-2016 yang dikaitkan dengan variabel $\mathrm{X}$ dalam penelitian ini:

Tabel 1

Pengungkapan CSR Menurut GRI Versi 4 Pada Perusahaan LQ-45 Tahun 2014-2016

\begin{tabular}{|c|c|c|c|c|c|c|c|c|c|c|}
\hline \multirow{2}{*}{$\begin{array}{l}\text { KODE } \\
\text { EMITEN }\end{array}$} & \multicolumn{3}{|c|}{$\begin{array}{l}\text { UKURAN } \\
\text { PERUSAHAAN }\end{array}$} & \multicolumn{3}{|c|}{$\begin{array}{l}\text { UKURAN } \\
\text { KOMISARIS }\end{array}$} & \multirow{2}{*}{$\begin{array}{l}\text { SENSITIVITAS } \\
\text { INDUSTRI } \\
2014 / 2015 / 2016\end{array}$} & \multicolumn{3}{|c|}{ PENGUNGKAPAN CSR } \\
\hline & 2014 & 2015 & 2016 & 2014 & 2015 & 2016 & & 2014 & 2015 & 2016 \\
\hline AALI & 7,268 & 7,332 & 7,384 & 6 & 5 & 5 & 1 & 0,57 & 0,69 & 0,70 \\
\hline$\overline{\text { ADHI }}$ & 7,019 & $\overline{7,224}$ & 7,303 & 6 & 6 & 6 & 0 & 0,19 & $\overline{0,19}$ & 0,19 \\
\hline AKRA & 7,170 & 7,181 & 7,199 & 3 & 3 & 3 & 1 & 0,35 & 0,57 & $\mathbf{0 , 4 9}$ \\
\hline ASII & 8,372 & 8,389 & 8,418 & 11 & 11 & 12 & 1 & 0,26 & 0,26 & 0,25 \\
\hline$\overline{\text { ASRI }}$ & 7,228 & $\overline{7,272}$ & 7,305 & 5 & 5 & 5 & $\mathbf{0}$ & 0,13 & 0,13 & 0,13 \\
\hline
\end{tabular}




\begin{tabular}{|c|c|c|c|c|c|c|c|c|c|c|}
\hline $\begin{array}{l}\text { KODE } \\
\text { EMITEN }\end{array}$ & \multicolumn{3}{|c|}{$\begin{array}{l}\text { UKURAN } \\
\text { PERUSAHAAN }\end{array}$} & \multicolumn{3}{|c|}{$\begin{array}{l}\text { UKURAN } \\
\text { KOMISARIS }\end{array}$} & \multirow{2}{*}{$\begin{array}{l}\text { SENSITIVITAS } \\
\text { INDUSTRI } \\
0\end{array}$} & \multicolumn{3}{|c|}{ PENGUNGKAPAN CSR } \\
\hline$\overline{\mathrm{BBCA}}$ & $\overline{8,742}$ & 8,772 & 8,830 & 5 & 5 & 5 & & $\overline{0,14}$ & 0,19 & $\overline{0,30}$ \\
\hline$\overline{\text { BBNI }}$ & 8,619 & 8,706 & 8,780 & 8 & $\overline{8}$ & 6 & 0 & 0,26 & 0,24 & $\overline{0,12}$ \\
\hline BBRI & 8,904 & 8,943 & 9,175 & 7 & 8 & 11 & $\mathbf{0}$ & 0,02 & 0,34 & 0,10 \\
\hline BMRI & 8,931 & 8,959 & 9,016 & 7 & 8 & 8 & 0 & 0,38 & 0,45 & 0,64 \\
\hline BMTR & 7,404 & 7,423 & 7,391 & 7 & 5 & 5 & 1 & 0,10 & 0,10 & 0,11 \\
\hline CPIN & 7,319 & 7,392 & 7,383 & 5 & 5 & 8 & 1 & 0,25 & 0,11 & 0,15 \\
\hline GGRM & $\mathbf{7 , 7 6 5}$ & $\mathbf{7 , 8 0 2}$ & 7,799 & 4 & 4 & 4 & 1 & 0,76 & 0,23 & 0,16 \\
\hline INDF & 7,934 & 7,962 & 7,914 & 8 & 8 & 8 & 1 & 0,22 & 0,24 & 0,24 \\
\hline INTP & 7,460 & 7,441 & 7,479 & 7 & 7 & 7 & 1 & 0,52 & 0,43 & 0,98 \\
\hline JSMR & $\mathbf{7 , 5 0 3}$ & $\mathbf{7 , 5 6 4}$ & 7,728 & 6 & 6 & 6 & $\mathbf{0}$ & 0,25 & 0,23 & $\mathbf{0 , 2 3}$ \\
\hline KLBF & 7,094 & 7,136 & 7,182 & 6 & 7 & 7 & 1 & 0,07 & 0,89 & 0,22 \\
\hline LPKR & 7,577 & 7,616 & 7,658 & 9 & 8 & 6 & 0 & 0,13 & 0,13 & 0,13 \\
\hline LSIP & 6,937 & 6,946 & 6,975 & 8 & 6 & 6 & 1 & 0,18 & 0,95 & 0,27 \\
\hline $\mathrm{MNCN}$ & 7,133 & 7,160 & 7,153 & 5 & 5 & 3 & 1 & 0,09 & 0,56 & 0,78 \\
\hline $\begin{array}{l}\text { PTBA } \\
\end{array}$ & 5,170 & 5,227 & 5,009 & 6 & 6 & 6 & 1 & 0,15 & 0,93 & $\overline{0,90}$ \\
\hline $\begin{array}{l}\text { PTPP } \\
\end{array}$ & 7,164 & 7,281 & 7,494 & 5 & 6 & 6 & 0 & 0,69 & 0,45 & 0,45 \\
\hline PWON & 7,224 & 7,273 & 7,315 & 3 & 3 & 3 & 0 & 0,11 & 0,12 & 0,19 \\
\hline SMGR & 7,535 & 7,581 & 7,645 & 7 & 7 & 7 & 1 & 0,53 & 0,35 & 0,21 \\
\hline SMRA & 7,186 & 7,273 & 7,318 & 4 & 4 & 4 & 0 & 0,10 & 0,11 & 0,13 \\
\hline TLKM & 8,151 & 8,220 & 8,254 & 7 & 7 & 7 & 1 & 0,29 & $\begin{array}{l}\mathbf{3}, 30 \\
\end{array}$ & 0,25 \\
\hline UNTR & 7,780 & 7,790 & 7,806 & 7 & 6 & 6 & 1 & 0,35 & 0,25 & 0,35 \\
\hline UNVR & 7,154 & 7,196 & 7,223 & 5 & 5 & 5 & 0 & 0,37 & 0,63 & 0,19 \\
\hline WIKA & 7,201 & 7,292 & 7,492 & 5 & 7 & 7 & 0 & 0,38 & 0,24 & 0,33 \\
\hline WSKT & 7,098 & 7,481 & 7,788 & 6 & 6 & 6 & 0 & 0,29 & 0,22 & 0,29 \\
\hline
\end{tabular}

Sumber: Hasil Penelitian, Data diolah (2017)

Dari tabel di atas dapat dilihat perusahaan dengan kode emiten ADHI mengalami kenaikan ukuran perusahaan pada tahun 2014-2016 yaitu $7,019,7,224,7,303$, akan tetapi pengungkapan CSR pada tahun 2014-2016 tetap sebesar 0,19, kemudian perusahaan dengan kode emiten AKRA mengalami peningkatan ukuran perusahaan pada tahun 2015-2016 sebesar 7,181 menjadi 7,199 akan tetapi pengungkapan CSRnya menurun pada tahun 2016 menjadi 0,49. Selanjutnya perusahaan dengan kode emiten ASII pada tahun 2016 menambah dewan komisarisnya menjadi 12 orang akan tetapi pengungkapan CSR perusahaan menurun pada tahun 2016 menjadi 0,25, perusahaan dengan kode emiten ASRI mengalami peningkatan ukuran perusahaan pada tahun 2014-2016 yaitu sebesar 7,228, 7,272, 7,305 akan tetapi pengungkapan CSRnya tetap sebesar 0,13 pada tahun tersebut.
Emiten BBNI pada tahun 2016 mengalami peningkatan ukuran perusahaan dari 8,7063 menjadi 8,780 akan tetapi pengungkapan CSRnya menurun pada tahun 2016 menjadi 0,12. Selanjutnya emiten BBRI mengalami peningkatan ukuran perusahaan pada tahun 2016 yaitu 9,175 dan melakukan penambahan dewan komisaris menjadi 11 orang akan tetapi pengungkapan CSR tahun 2016 menurun dari tahun sebelumnya menjadi 0,10 , selanjutnya GGRM mengalami peningkatan ukuran perusahaan pada tahun 2015 yaitu 7,802 akan tetapi pengungkapan CSR tahun 2015 mengalami penurunan menjadi 0,23, JSMR mengalami peningkatan ukuran perusahaan pada tahun 2016 yaitu 7,728 akan tetapi pengungkapan CSRnya masih sama seperti tahun 2015 yaitu sebesar 0,23. LPKR mengalami peningkatan ukuran perusahaan tahun 2014-2016 yaitu 7,577, 7,616, 7,658 akan tetapi pengungkapan CSRnya masih sama setiap tahun tersebut yaitu 0,13 , LSIP 
mengalami peningkatan ukuran perusahaan pada tahun 2016 yaitu 6,975 akan tetapi pengungkapan CSRnya turun dari tahun sebelumnya yaitu menjadi 0,27, SMGR mengalami peningkatan ukuran perusahaan tahun 2014-2016 yaitu 5,758, 7,581, 7,645 akan tetapi pengungkapan CSR tahun 2015 dan 2016 menurun menjadi 0,53, 0,35, 0,21.

TLKM mengalami peningkatan ukuran perusahaan pada tahun 2016 yaitu 8,254 akan tetapi pengungkapan CSR tahun 2016 menurun dari tahun sebelumnya menjadi 0,25. Selanjutnya UNTR mengalami peningkatan ukuran perusahaan tahun 2015 yaitu 7,790 akan tetapi pengungkapan CSR tahun 2015 menurun dari tahun sebelumnya menjadi 0,25, UNVR juga mengalami hal yang sama yaitu bertambahnya ukuran perusahaan tahun

2016 yaitu 7,223 akan tetapi pengungkapan CSR tahun 2016 menurun menjadi 0,19, Emiten WIKA mengalami kenaikan ukuran perusahaan pada tahun 2015 yaitu 7,292 akan tetapi pengungkapan CSRnya menurun menjadi 0,24, WSKT juga mengalami hal yang sama dengan perusahaan sebelumnya. Emiten WSKT juga mengalami peningkatan ukuran perusahaan pada tahun 2015 yaitu sebesar 7,481 akan tetapi pengungkapan CSRnya berkurang dari tahun sebelumnya yaitu menjadi 0,22 .

Dari beberapa hal yang telah disebutkan di atas, hal tersebut tidak sejalan dengan teori legitimasi yang mengatakan bahwa perusahaan yang lebih besar melakukan aktivitas yang lebih banyak sehingga memiliki pengaruh yang lebih besar terhadap masyarakat, untuk memperoleh legitimasi dari masyarakat maka perusahaan akan mengungkapkan CSR yang lebih luas dibandingkan dengan perusahaan kecil. Hal serupa juga diungkapkan oleh Subiantoro (2015) yang mengatakan perusahaan besar akan mengungkapkan informasi lebih banyak dari pada perusahaan kecil karena perusahaan besar akan menghadapi resiko politis yang lebih besar dibanding perusahaan kecil.

Berdasarkan hal tersebut menjadikan penelitian ini penting serta membuat peneliti tertarik untuk meneliti CSR dikarenakan pengungkapan CSR pada perusahaan LQ-45 tahun 2014-2016 bertentangan dengan teori yang ada. Inilah yang menjadi permasalahan (fenomena gap) dalam penelitian ini.

\section{TINJAUAN PUSTAKA}

\section{Corporate Social Responsibility (CSR)}

Purwanto (2011) mendefinisikan CSR sebagai komitmen perusahaan untuk mempertanggungjawabkan dampak operasinya dalam dimensi sosial, ekonomi, dan lingkungan serta terus menerus dampak tersebut memberikan manfaat kepada masyarakat dan lingkungan. CSR merupakan komitmen berkelanjutan dari perusahaan untuk berperilaku dengan etis dan memberikan kontribusi kepada pengembangan ekonomi sekaligus meningkatkan kualitas hidup tenaga kerja dan keluarganya.

\section{Ukuran Perusahaan}

Ukuran perusahaan merupakan salah satu variabel yang umum digunakan untuk menjelaskan mengenai variasi pengungkapan dalam laporan tahunan perusahaan. Berkembang suatu fenomena bahwa pengaruh total aktiva (proksi dari ukuran perusahaan) hampir selalu konsisten dan secara signifikan berpengaruh terhadap kualitas pengungkapan. Hal ini dibuktikan oleh Cooke (1989) dalam Pian (2010) yaitu perusahaan besar mempunyai biaya informasi yang rendah, perusahaan besar juga mempunyai kompleksitas dan dasar pemilikan yang lebih luas dibanding perusahaan kecil.

Teori legitimasi memiliki alasan tentang hubungan ukuran dan pengungkapan. Perusahaan yang lebih besar melakukan aktivitas yang lebih banyak sehingga memiliki pengaruh yang lebih besar terhadap masyarakat, memilik lebih banyak pemegang saham yang punya perhatian terhadap program sosial yang dilakukan perusahaan dan laporan tahunan merupakan alat yang efisien untuk mengkomunikasikan informasi ini (Cowen et Al., 1987) dalam Zaenuddin (2007).

\section{Ukuran Dewan Komisaris}

Komisaris merupakan organ perseroan yang memegang fungsi pengawasan. Komisaris terdiri dari beberapa orang, sehingga lebih dikenal dengan dewan komisaris. Dewan komisaris adalah organ perseroan yang bertugas melakukan pengawasan secara umum dan atau khusus sesuai dengan anggaran dasar serta memberi nasehat kepada dewan direksi. Dewan komisaris melakukan pengawasan atas kebijakan pengurusan jalannya pengurusan pada umumnya, baik mengenai perseroan maupun usaha perseroan dan memberi 
nasehat kepada direksi. Pengawasan tersebut dilakukan untuk kepentingan perseroan dan sesuai dengan maksud dan tujuan perseroan. pengawasan dan pemberian nasehat yang dilakukan oleh dewan komisaris tidak untuk kepentingan pihak atau golongan tertentu tetapi untuk kepentingan perseroan secara menyeluruh.

Dewan komisaris sangat diperhitungkan untuk menunjang kinerja perusahaan dalam hal pengawasan dewan direksi, jumlah komisaris yang ideal akan mempengaruhi progres dari kinerja perusahaan, jumlah anggota komisaris juga tergantung kepada bidang usaha dan jenis industri perusahaan.

\section{Sensitivitas Industri}

Sensitivitas industri dapat diartikan sebagai seberapa besar pengaruh aktivitas industri yang bersinggungan langsung dengan lingkungan. Pada umumnya perusahaan dengan tingkat sensitivitas industri yang tinggi terhadap lingkungan akan memperoleh perhatian yang tinggi pula dari masyarakat karena aktivitas operasinya yang memiliki potensi mempengaruhi alam. Anggraini (2006) menggambarkan perusahaan yang memiliki tingkat sensitivitas industri tinggi akan memperoleh perhatian yang lebih dari masyarakat dan kepentingan lain karena aktivitas industri yang berpotensi mempengaruhi kepentingan luas, baik dari segi ekonomi, sosial dan lingkungan. Hasil penelitiannya menyatakan sensitivitas industri berpengaruh secara signifikan terhadap pengungkapan tanggung jawab sosial.

\section{PENELITIAN TERDAHULU}

1. Subiantoro (2015)

Pengaruh ukuran perusahaan, leverage, profitabilitas, tipe industri kepemilikan manajemen, dewan komisaris terhadap pengungkapan tanggung jawab sosial perusahaan (corporate social responsibility). Hasil analisis data menunjukkan bahwa ukuran perusahaan, leverage, profitabilitas, tipe industri kepemilikan manajemen, tidak berpengaruh terhadap pengungkapan tanggung jawab sosial perusahaan (corporate social responsibility). Dewan komisaris berpengaruh terhadap pengungkapan tanggung jawab sosial perusahaan (corporate social responsibility.
2. Anggraini (2006)

Pengungkapan Informasi Sosial dan Faktor-Faktor yang Mempengaruhi Pengungkapan Informasi Sosial dalam Laporan Keuangan Tahunan (Studi Empiris pada Perusahaan-Perusahaan yang terdaftar Bursa Efek Jakarta) dengan hasil penelitiannya yaitu persentase kepemilikan manajemen (MAN) dan tipe industri (IND) yang berpengaruh signifikan terhadap kebijakan perusahaan dalam mengungkapkan informasi sosial dengan arah sesuai dengan yang diprediksi. Penelitian ini tidak berhasil membuktikan pengaruh ukuran perusahaan, leverage dan profitabilitas terhadap kebijakan pengungkapan informasi sosial oleh perusahaan.

3. Purwanto (2011)

Pengaruh tipe industri, ukuran perusahaan, profitabilitas, Terhadap corporate social responsibility. Hasil penelitian menunjukkan bahwa tipe industri dan ukuran perusahaan berpengaruh signifikan terhadap pengungkapan pertanggungjawaban sosial sedangkan profitabilitas tidak berpengaruh signifikan terhadap pengungkapan pertanggungjawaban sosial.

Berdasarkan tinjauan pustaka dan hasil penelitian-penelitian terdahulu maka dirumuskan sebagai berikut:

H1: Ukuran perusahaan berpengaruh terhadap pengungkapan Corporate Social Responsibility.

$\mathrm{H} 2$ : Ukuran dewan komisaris berpengaruh terhadap pengungkapan pengungkapan Corporate Social Responsibility.

H3: Sensitivitas industri berpengaruh terhadap pengungkapan Corporate Social Responsibility.

H4 : Ukuran perusahaan, ukuran dewan komisaris, dan sensitivitas industri berpengaruh secara simultan terhadap pengungkapan Corporate Social Responsibility.

\section{METODE PENELITIAN}

Objek dalam penelitian ini yaitu Ukuran Perusahaan $\left(\mathrm{X}_{1}\right)$, Ukuran Dewan Komisaris $\left(\mathrm{X}_{2}\right)$, Sensitivitas Industri $\left(\mathrm{X}_{\mathrm{g}}\right)$ dan Pengungkapan CSR (Y). Lokasi penelitian ini adalah pada perusahaan 
LQ-45 yang terdaftar di Bursa Efek Indonesia tahun 2014 - 2016.

\section{POPULASI DAN SAMPEL}

Populasi dalam penelitian ini adalah perusahaan-perusahaan yang pernah masuk dalam kelompok indeks LQ-45 di BEI tahun 2014 - 2016 sebanyak 58 perusahaan. Metode yang digunakan dalam pemilihan objek pada penelitian ini adalah Purposive Sampling, yaitu teknik penentuan sampel dengan pertimbangan tertentu (Sugiyono, 2013:124). Adapun kriteria dalam penelitian ini, yaitu: (1) Perusahaan yang pernah masuk indeks LQ-45 yang terdaftar di Bursa efek Indonesia tahun 2014-2016, (2) Perusahaan berturut-turut termasuk ke dalam indeks LQ-45 selama tiga periode yaitu 2014-2016, (3) Perusahaan LQ-45 yang menyajikan laporan keuangan tahun 2014-2016 dalam satuan rupiah. Berdasarkan kriteria tersebut dari jumlah populasi sebanyak 58 perusahaan, maka diperoleh sebanyak 29 perusahaan yang memenuhi kriteria sebagai sampel. Total sampel sebanyak 87 perusahaan.

\section{TEKNIK PENGUMPULAN DATA}

Dalam penelitian ini menggunakan data kuantitatif, yaitu data penelitian berupa angkaangka dan analisis menggunakan statistik (Sugiyono, 2013:13). Jenis data yang digunakan dalam penelitian ini berupa data sekunder, yakni annual report dan laporan keuangan perusahaan tahun 2014-2016. Data sekunder ini diambil dari database Bursa Efek Indonesia, dan website perusahaa.

Teknik pengambilan data yang digunakan adalah teknik dokumentasi, yaitu penggunaan data yang berasal dari dokumen-dokumen yang sudah ada dengan cara mengumpulkan, mencatat dan mengolah data sekunder berupa laporan tahunan dari perusahaan LQ-45 yang terdaftar di BEI. Data dalam penelitian ini berasal dari situs IDX (Indonesia Stock Exchanges) yang dimiliki oleh website BEI, yakni www.idx.co.id, website perusahaan dan juga dari jurnal dan buku yang berkaitan dengan penelitian ini.

\section{DEFINISI OPERASIONAL VARIABEL PENELITIAN \\ Pengungkapan Corporate Social Responsibility}

Pengukuran pengungkapan CSR diukur dengan proksi CSR Disclosure Index (CSRI), mengacu pada indikator pengungkapan GRI (Global Reporting Initiatives) versi 4.

Jumlah item pengungkapan CSR menurut GRI adalah 91 yang terdiri dari ekonomi (9 item), lingkungan (34 item), praktik tenaga kerja (16 item), hak manusia (12 item), masyarakat (11 item), dan tanggung jawab produk (9 item). Untuk mengukurnya digunakan metode content analysis seperti yang digunakan dalam penelitian Nurkhin (2009). Setiap item CSR dalam instrumen penelitian diberi nilai 1 jika diungkapkan, dan nilai 0 jika tidak diungkapkan. Selanjutnya, skor dari setiap item dijumlahkan untuk memperoleh keseluruhan skor untuk setiap perusahaan. Rumus perhitungan CSRI menurut Nurkhin (2009) dan modifikasi penulis dengan peraturan GRI 4 adalah sebagai berikut:

$\operatorname{CSRI}_{\mathrm{i}=} \frac{\sum \mathrm{Xyi}}{91}$

Keterangan :

$\mathrm{CSRI}_{\mathrm{i}} \quad=$ Skor Corporate Social Responsibility Disclosure Index perusahaan i

$\sum$ Xyi = Jumlah item yang diungkapkan setelah diukur dengan dummy variable.

Dummy variable, nilai 1 jika item y diungkapkan; nilai 0 jika item y tidak diungkapkan.

\section{Ukuran Perusahaan}

Penelitian variabel ukuran perusahaan diukur dengan logaritma natural total asset. Pengukuran ini berdasarkan pada penelitian Purwanto (2010) yang dirumuskan sebagai berikut:

$\mathrm{SIZE}=\log$ (nilai total aktiva).

\section{Ukuran Dewan Komisaris}

Sebagaimana penelitian yang dilakukan sembiring (2005), ukuran dewan komisaris diukur melalui jumlah dewan komisari dengan rumus sebagai berikut:

$\mathrm{UDK}=\Sigma$ Dewan Komisaris

\section{Sensitivitas Industri}

Sensitivitas industri diukur melalui tipe industri yaitu high profil dan low profil. Kelompok industri yang termasuk high profil yaitu perusahaan perminyakan dan pertambangan lain, kimia, hutan, kertas, otomotif, penerbangan, agribisnis, tembakau dan rokok, produk makanan dan minuman, media dan komunikasi, energi (listrik), engineering, kesehatan serta transportasi dan pariwisata. Sedangkan kelompok industri low profile terdiri 
dari bangunan, keuangan dan perbankan, supplier peralatan medis, properti, retailer, tekstil dan produk tekstil, produk personal, dan produk rumah tangga (Purwanto 2011). Pengukurannya digunakan variabel dummy, yaitu dengan memberikan nilai 1 untuk perusahaan sensitivitas industri tinggi dan 0 untuk perusahaan sensitivitas industri rendah (Purwanto 2011).

\section{TEKNIK ANALISIS DATA}

Teknik analisis data dalam penelitian ini menggunakan Analisis Statistik Deskriptif, Pengujian Asumsi Klasik, Uji Normalitas, Uji Multikolinearitas, Uji Autokorelasi, Uji Heteroskedastisitas dan Uji Regresi Linear Berganda, dimana model regresinya sebagai berikut:

$$
Y=\alpha+\beta_{1} X_{1}+\beta_{2} X_{2}+\beta_{3} X_{3}+€
$$

Keterangan:

$\mathrm{Y} \quad=$ Variabel dependen (pengungkapan CSR).

$$
\begin{array}{ll}
\alpha & =\text { Konstanta } \\
\beta & =\text { Koefisien regresi } \\
X_{1} & =\text { Ukuran perusahaan } \\
X_{2} & =\text { Ukuran dewan komisaris } \\
X_{a} & =\text { Sensitivitas industri } \\
€ & =\text { Error term }
\end{array}
$$

\section{HASIL PENELITIAN DAN PEMBAHASAN STATISTIK DESKRIPTIF}

Analisis Deskriptif ini digunakan untuk memberikan gambaran atau deskripsi mengenai variabel independen yaitu ukuran perusahaan, ukuran dewan komisaris dan sensitivitas industri pada perusahaan LQ-45 yang terdaftar di BEI tahun 2014-2016. Deskriptif data variabel yang ada dalam penelitian ini dapat dilihat dalam tabel berikut:

Tabel 2 Descriptive Statistics Deskriptif Data Penelitian

\begin{tabular}{|l|l|l|l|l|l|}
\hline & & Minimum & Maximum & Mean & Std. Deviation \\
\hline USR & 87 & .02 & .98 & .3234 & .22969 \\
UP & 87 & 5.009 & 9.175 & 7.50831 & .738152 \\
UDK & 87 & 3 & 12 & 6.13 & 1.822 \\
SI & 87 & 0 & 1 & .49 & .503 \\
\hline
\end{tabular}

Descriptive Statistics

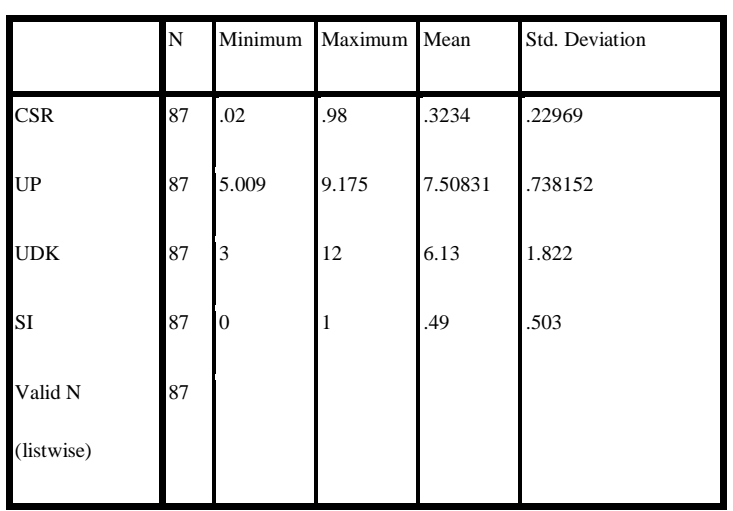

Sumber: Hasil Penelitian, Data diolah 2017

\section{UJI ASUMSI KLASIK}

\section{Uji Normalitas}

Uji normalitas digunakan untuk menguji apakah dalam model regresi, variabel pengganggu atau residual memiliki distribusi normal. Model regresi yang baik adalah yang memiliki distribusi normal atau mendekati normal. Salah satu metode yang dapat digunakan dalam uji normalitas adalah metode normal probability plot, yang membandingkan distribusi kualitatif dari data sesungguhnya dengan distribusi kualitatif dari distribusi normal. Distribusi normal akan membentuk satu garis lurus diagonal dan ploting data akan dibandingkan dengan garis diagonal. Jika distribusi data adalah normal, maka garis yang menggambarkan data sesungguhnya akan mengikuti garis diagonalnya.

Hasil uji normalitas dalam penelitian ini dapat dilihat pada gambar berikut ini:

\section{Gambar 1 \\ Grafik Normal Probability Plot Setelah Tranformasi}

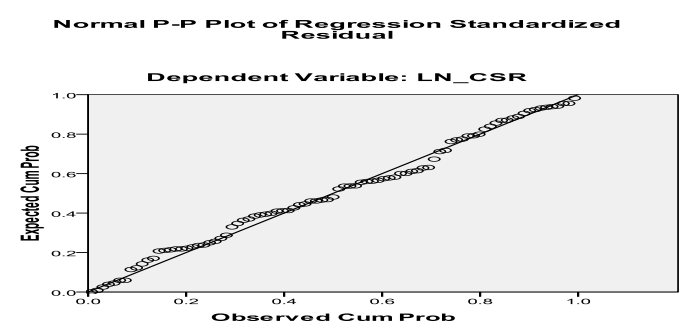

Sumber: Hasil Penelitian, Data diolah (2017)

\section{Uji Multikolinearitas}

Uji multikolinearitas adalah situasi adanya korelasi variabel-variabel bebas diantara satu dengan yang lain model regresi berganda harus 
terbebas dari multikolinearitas untuk satu variabel dependennya. Untuk mendeteksi ada tidaknya multikolinearitas dalam model regresi dapat dilihat dari nilai tolerance dan variance inflation factor (VIF). Kedua ukuran ini menunjukkan setiap variabel bebas manakah yang dijelaskan oleh variabel lainnya. Dalam pengertian yang sederhana, setiap variabel bebas menjadi variabel terikat dan diregresi terhadap variabel bebas lainnya. Tolerance mengukur variabilitas variabel bebas yang terpilih yang tidak dapat dijelaskan dalam variabel bebas lainnya. Jika nilai Tolerance $<0,10$ atau VIF>dari 10 maka terjadi multikolinearitas. Hasil pengujian multikolinearitas adalah sebagai berikut:

Tabel 3

Hasil Uji Multikolinearitas

Coefficients $^{\mathrm{a}}$

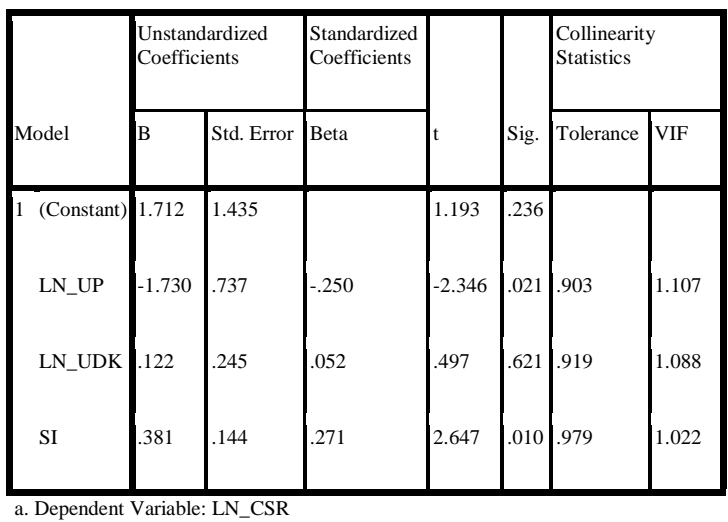

Sumber: Hasil Penelitian, Data diolah (2017).

\section{Uji Autokorelasi}

Uji autokorelasi digunakan menguji apakah dalam model regresi linear ada korelasi antara kesalahan pengganggu pada periode $\mathrm{t}$ dengan kesalahan pengganggu pada periode $\mathrm{t}-1$ (sebelumnya) maka digunakan uji autokorelasi. Pengujian autokorelasi dapat dilakukan dengan menghitung Durbit-Watson (d), dengan membandingkan nilai $\mathrm{d}$ terhadap $\mathrm{d} 1$ dan du. Setelah menghitung nilai statistik selanjutnya dibandingkan dengan tabel, dengan tingkat signifikan 5\%. Menurut Ghozali (2006:95) pengambilan keputusan autokorelasi ada 5 dapat dilihat pada tabel berikut ini:
Tabel 4

Daerah Pengambilan Keputusan Uji Durbin-

Watson

\begin{tabular}{|l|l|l|}
\hline Hipotesis nol & Keputusan & Jika \\
\hline Tidak ada autokorelasi positif & Tolak & $0<\mathrm{d}<\mathrm{dl}$ \\
\hline Tidak ada autokorelasi positif & No decision & $\mathrm{dl} \leq \mathrm{d} \leq \mathrm{du}$ \\
\hline Tidak ada autokorelasi negatif & Tolak & $4-\mathrm{dl}<\mathrm{d}<4$ \\
\hline Tidak ada autokorelasi negatif & No decision & $4-\mathrm{du} \leq \mathrm{d} \leq 4-\mathrm{dl}$ \\
\hline $\begin{array}{l}\text { Tidak ada autokorelasi positif dan } \\
\text { negatif }\end{array}$ & Tolak & $\mathrm{du}<\mathrm{d}<4-\mathrm{du}$ \\
\hline
\end{tabular}

Sumber : Ghozali (2006:95).

Perhitungan hasil uji autokorelasi pada penelitian ini bisa kita lihat pada tabel 5 berikut ini:

Tabel 5

Hasil Uji Autokorelasi

Model Summary ${ }^{b}$

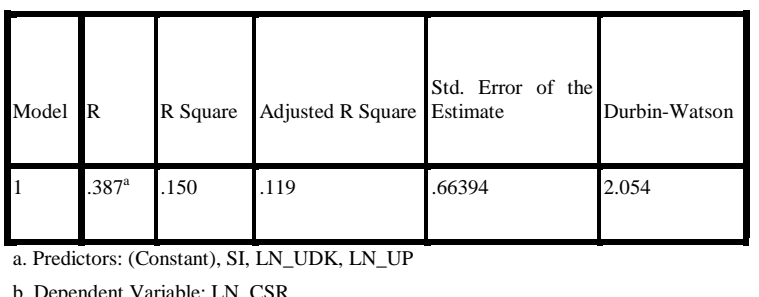

Sumber: Hasil Penelitian, Data diolah 2017.

\section{Uji Heteroskedastisitas}

Uji Heteroskedastisitas bertujuan untuk menguji apakah dalam model regresi terjadi ketidaksamaan variance dari residual satu pengamatan ke pengamatan yang lain. Jika variance dari residual tetap maka disebut homoskedastisitas, namun apabila berbeda maka disebut heteroskedastisitas.. Model regresi yang baik adalah yang homoskedastisitas atau tidak terjadi heteroskedastisitas. Salah satu cara untuk mendeteksi ada tidaknya heteroskedastisitas adalah melihat grafik plot antara nilai prediksi variabel terikat (dependen) yaitu ZPRED dengan residualnya SRESID. Deteksi ada tidaknya heteroskedastisitas dapat dilakukan dengan melihat ada tidaknya pola tertentu pada grafik scatterplot antara SRESID dan ZPRED di mana sumbu Y adalah $\mathrm{Y}$ yang telah diprediksi, dan sumbu $\mathrm{X}$ adalah residual (Y prediksi-Ysesungguhnya) yang telah di-studentized.

Adapun hasil sccatterplot pengujian heteroskedastisitas dengan menggunakan metode grafik dapat dilihat dari gambar 2 sebagai berikut: 


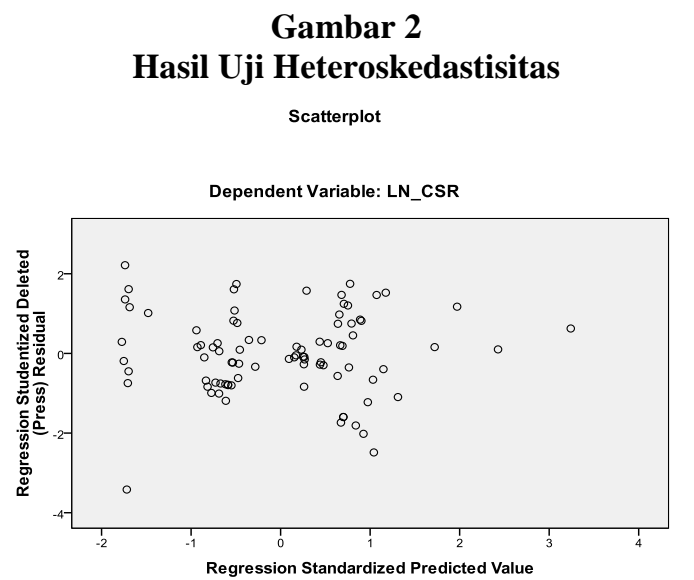

Sumber: Hasil Penelitian, Data diolah (2017).

\section{Analisis Regresi Linear Berganda}

Suatu penelitian membutuhkan analisis data dan interpretasinya yang bertujuan menjawab pertanyaan-pertanyaan yang ada dalam mengungkap fenomena tertentu. Analisis data adalah proses penyederhanaan data ke dalam bentuk yang lebih mudah dibaca dan di interpretasikan. Dalam uji ini model regresi yang digunakan adalah model regresi linear berganda, dimana Ukuran perusahaan (X1), Ukuran dewan komisaris (X2) dan sensitivitas industri (X3) sebagai variabel independen dan pengungkapan CSR (Y) sebagai variabel dependen. Hasil regresi dapat dilihat pada tabel 4.5 berikut:

Berdasarkan hasil regresi pada tabel 6, maka diperoleh persamaan regresi linear berganda sebagai berikut:

Tabel 6

Hasil Regresi Linear Berganda

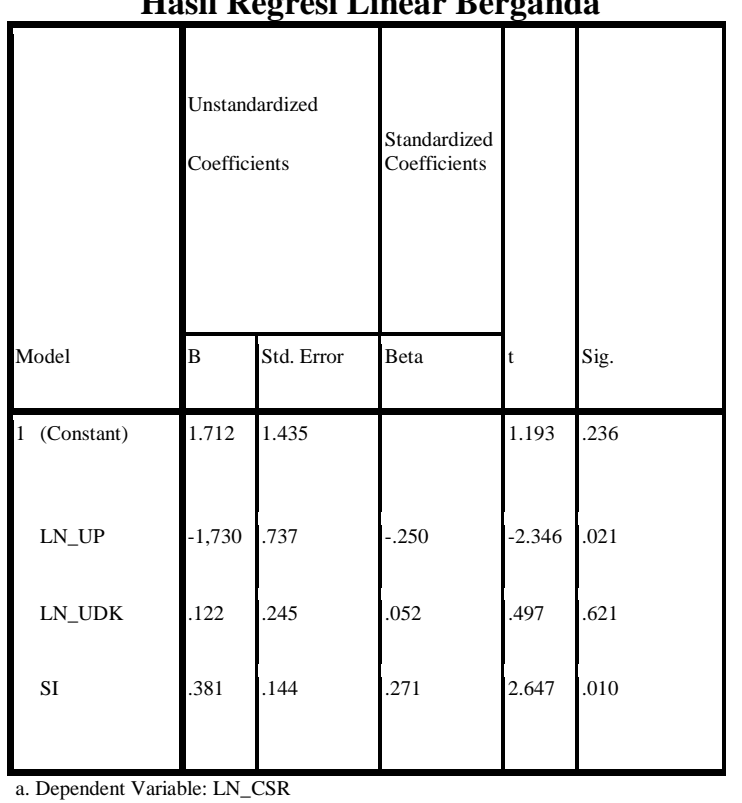

Sumber: Hasil Penelitian, Data diolah (2017).
$\mathbf{Y}=\alpha+\beta_{1} \mathbf{X}_{1}+\beta_{2} \mathbf{X}_{2}+\beta_{3} \mathbf{X}_{3}+\boldsymbol{\epsilon}$

$\mathrm{LN} \_\mathrm{CSR}=1,712-1,730 \mathrm{UP} \quad+\quad 0,122 \mathrm{UDK} \quad+$ $0,381 \mathrm{SI}+\mathrm{e}$

Dari persamaan regresi linear berganda di atas dapat dijelaskan bahwa:

1. konstanta $(\alpha)$ sebesar 1,712 artinya jika variabel UP, UDK dan SI dianggap konstan (bernilai 0), maka nilai LN_CSR tetap sebesar 1,712 .

2 Nilai koefisien regresi UP sebesar $-1,730$ menunjukkan hubungan negatif (terbalik) yang memberi arti bahwa setiap kenaikan UP sebesar $1 \%$ maka menyebabkan LN_CSR menurun sebesar -1,730 dengan asumsi variabel lain adalah konstan (cateris paribus).

3 Kemudian nilai koefisien regresi UDK sebesar 0,122 menunjukkan hubungan positif (searah) yang memberi arti bahwa setiap kenaikan UDK sebesar $1 \%$ maka menyebabkan LN_CSR meningkat sebesar 0,122 dengan asumsi variabel lain adalah konstan (cateris paribus).

4 Koefisien regresi SI sebesar 0,381 menunjukkan hubungan positif (searah) yang memberi arti bahwa setiap kenaikan SI sebesar $1 \%$ maka menyebabkan LN_CSR naik sebesar 0,381 dengan asumsi variabel lain adalah konstan (cateris paribus).

H1: Ukuran perusahaan berpengaruh signifikan terhadap pengungkapan corporate social responsibility pada perusahaan LQ-45 yang terdaftar di BEI tahun 2014-2016.

$\mathrm{H} 2$ : Ukuran dewan komisaris tidak berpengaruh signifikan terhadap pengungkapan corporate social responsibility pada perusahaan LQ-45 yang terdaftar di BEI tahun 2014-2016.

H3: Sensitivitas industri berpengaruh signifikan terhadap pengungkapan corporate social responsibility pada perusahaan LQ-45 yang terdaftar di BEI tahun 2014-2016.

\section{PENGUJIAN HIPOTESIS}

UJI T

Pengaruh Ukuran Perusahaan (X1) Terhadap Pengungkapan Corporate Social Responsibility

Berdasarkan hasil uji t diperoleh nilai t hitung dari Ukuran perusahaan sebesar -2,346 dengan nilai signifikasi dari Ukuran Perusahaan (UP) sebesar 
0,021<0,05, maka keputusan menerima $H 1$, yang artinya variabel Ukuran Perusahaan (UP) berpengaruh terhadap pengungkapan Corporate Social Responsibility pada perusahaan-perusahaan LQ-45 yang terdaftar di BEI tahun 2014-2016.

\section{Pengaruh Ukuran Dewan Komisaris (X2) Terhadap Pengungkapan Corporate Social Responsibility}

Berdasarkan hasil uji t diperoleh nilai t hitung Ukuran Dewan Komisaris sebesar 0,497 dengan nilai signifikasi dari Ukuran Dewan Komisaris (UDK) sebesar 0,621>0,05, maka keputusan menolak H2, artinya variabel UDK tidak berpengaruh terhadap pengungkapan Corporate Social Responsibility pada perusahaan-perusahaan LQ-45 yang terdaftar di BEI tahun 2014-2016.

\section{Pengaruh Sensitivitas Industri (X3) Terhadap Pengungkapan Corporate Social Responsibility}

Berdasarkan hasil uji $\mathrm{t}$ diperoleh nilai t hitung Sensitivitas Industri sebesar 2,647 dan nilai signifikansi dari Sensitivitas Industri sebesar $0,010<0,05$, maka keputusan menerima $\mathrm{H} 3$, artinya variabel Sensitivitas Industri berpengaruh terhadap pengungkapan Corporate Social Responsibility pada perusahaan-perusahaan LQ-45 yang terdaftar di BEI tahun 2014-2016.

\section{Uji F}

Pada prinsipnya pengujian simultan dilakukan dengan koefisien regresi secara bersama-sama untuk mengetahui apakah terdapat pengaruh secara serentak variabel independen terhadap variabel dependen. Uji $F$ pad penelitian ini dilakukan dengan melihat nilai signifikansi f pada output hasil regresi menggunakan SPSS dengan signifikan level $0,05(\alpha=5 \%)$. Jika nilai signifikansi lebih besar dari $\alpha$ maka hipotesis ditolak (koefisien regresi tidak signifikan), yang berarti secara simultan variabel-variabel bebas tidak mempunyai pengaruh yang signifikan terhadap variabel terikat. Jika nilai signifikan lebih kecil dari $\alpha$ maka hipotesis diterima (koefisien regresi signifikan). Ini berarti bahwa secara simultan variabel-variabel bebas mempunyai pengaruh yang signifikan terhadap variabel terikat. Hasil uji f pada penelitian ini adalah sebagai berikut:
Tabel 7

Hasil Uji F

ANOVA $^{\mathrm{b}}$

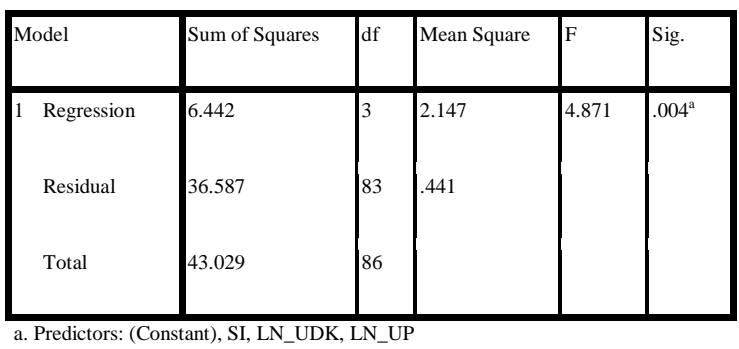

b. Dependent Variable: LN_CSR

Sumber: Hasil Penelitian, Data diolah (2017).

Berdasarkan hasil uji $\mathrm{F}$, diperoleh nilai signifikansi sebesar 0,004. Karena signifikan lebih kecil daripada nilai alpha 0,05 , maka model regresi dapat digunakan untuk memprediksi Probability (Y) atau dapat dikatakan bahwa Ukuran perusahaan, Ukuran Dewan Komisaris dan Sensitivitas Industri secara bersama-sama (simultan) berpengaruh terhadap pengungkapan corporate social responsibility.

\section{PEMBAHASAN HASIL PENELITIAN}

\section{Pengaruh Ukuran Perusahaan (X1) Terhadap Pengungkapan Corporate Social Responsibility}

Hasil uji signifikansi parsial (uji t) menunjukkan bahwa Ukuran Perusahaan (UP) berpengaruh negatif dan signifikan terhadap pengungkapan Corporate Social Responsibility. Hal ini dapat dilihat dari tingkat signifikansi Ukuran Perusahaan sebesar 0,021 artinya lebih kecil daripada 0,05. Dengan demikian penelitian ini menerima H1 yang berarti bahwa Ukuran Perusahaan berpengaruh signifikan terhadap pengungkapan Corporate Social Responsibility.

Berdasarkan hasil penelitian ini, semakin besar ukuran perusahaan akan semakin menurunkan jumlah pengungkapan corporate social responsibility. Karena bertambahnya aset perusahaan menunjukkan bertambahnya ukuran sebuah perusahaan menciptakan risiko bagi peningkatan biaya mengingat akan timbulnya aset yang menganggur atau tidak termanfaatkan untuk mendorong peningkatan nilai bagi perusahaan. Sehingga dengan adanya peningkatan biaya yang dikeluarkan perusahaan terhadap aset yang menganggur akan mengurangi jatah biaya yang digunakan untuk pengungkapan CSR.

Hasil penelitian ini telah sesuai dengan penelitian Saputra (2016), Palepu (2005) dan Ross 
(2012) yang menyatakan bahwa ukuran perusahaan berpengaruh negatif dan signifikan terhadap pengungkapan CSR. Hal ini disebabkan karena keberadaan aset yang menganggur memaksa perusahaan melakukan pengeluaran biaya yang lebih besar sehingga mengurangi jatah biaya yang digunakan untuk mengungkapkan corporate social responsibility.

\section{Pengaruh Ukuran Dewan Komisaris (X2) Terhadap Pengungkapan Corporate Social Responsibility}

Hasil uji signifikansi parsial (uji t) menunjukkan bahwa Ukuran Dewan Komisaris (UDK) tidak berpengaruh terhadap pengungkapan Corporate Social Responsibility. Hal ini dapat dilihat dari tingkat signifikansi Ukuran Dewan Komisaris sebesar 0,621 artinya lebih besar daripada 0,05. Dengan demikian penelitian ini menolak H2 yang berarti bahwa Ukuran Dewan Komisaris tidak berpengaruh signifikan terhadap pengungkapan Corporate Social Responsibility.

Hal ini terjadi mungkin karena tidak berfungsinya dewan komisaris atau dewan komisaris tidak menjalankan peran pengawasannya yang optimal terhadap pihak direksi atau manajemen. Manajemen sebagai pengurus perusahaan mempunyai ruang untuk bertindak bebas dan bertindak untuk kepentingan investor. Untuk dapat berhasil di pasar persaingan maka manajemen harus melakukan inovasi dan strategi yang bisa mendukung hal tersebut. Salah satunya seperti pengungkapan CSR. Jika manajemen menilai pengungkapan CSR sebagai nilai tambah bagi perusahaan, maka manajemen akan melakukan pengungkapan CSR walaupun tanpa adanya pengawasan dari dewan komisaris.

Sebab tidak berfungsinya dewan komisaris dapat saja terjadi karena banyak dewan komisaris tidak memiliki kemampuan dan tidak menunjukkan independensinya sehingga dewan komisaris juga gagal untuk mewakili kepentingan stakeholder. Kepemilikan saham yang terpusat dalam satu kelompok atau satu keluarga dapat menjadi salah satu penyebab lemahnya posisi dewan komisaris, karena pengangkatan posisi dewan komisaris diberikan sebagai rasa penghargaan semata maupun berdasarkan hubungan keluarga atau kenalan dekat.

Hal ini sejalan dengan penelitian yang dilakukan oleh Arifin (2013), Wijaya (2012) dan fahrizqi (2010) yang mengatakan bahwa ukuran dewan komisaris tidak mempunyai pengaruh terhadap pengungkapan CSR. Hal ini disebabkan karena dewan komisaris merupakan wakil shareholders dalam perusahaan yang berfungsi mengawasi pengelolaan perusahaan yang dilakukan oleh manajemen. Sebagai wakil dari shareholders dewan komisaris akan membuat kebijakan menggunakan laba perusahaan untuk aktivitas operasional perusahaan yang lebih menguntungkan daripada melakukan aktivitas sosial.

\section{Pengaruh Sensitivitas Industri (X3) Terhadap Pengungkapan Corporate Social Responsibility}

Hasil uji signifikansi parsial (uji t) menunjukkan bahwa Sensitivitas Industri (SI) berpengaruh terhadap pengungkapan Corporate Social Responsibility. Hal ini dapat dilihat dari tingkat signifikansi Sensitivitas Industri sebesar 0,010 artinya lebih kecil daripada 0,05 . Dengan demikian penelitian ini menerima $\mathrm{H} 3$ yang berarti bahwa Sensitivitas Industri berpengaruh signifikan terhadap pengungkapan Corporate Social Responsibility.

Hal tersebut disebabkan karena perusahaan yang memiliki sensitivitas yang tinggi atau tipe perusahaan high profile berpotensi mempengaruhi kepentingan luas, baik dari segi ekonomi, sosial dan lingkungann. Perusahaan high profile juga mengungkapkan lebih banyak CSR dikarenakan tuntutan dari pemerintah yang mewajibkan perusahaan high profile seperti perusahaan pertambangan dan beberapa perusahaan lainnya untuk mengungkapkan tanggung jawab lingkungannya yang lebih besar.

Hasil penelitian ini sejalan dengan penelitian yang dilakukan oleh Purwanto (2011), Djakman dan Machmud (2008) dan Yuliana (2008) yang mengatakan bahwa tipe industri berpengaruh terhadap pengungkapan CSR. Hasil penelitiannya menunjukkan bahwa perusahaan yang termasuk klasifikasi high profile berjumlah 48 perusahaan. Dari 48 perusahaan tersebut, terdapat 21 perusahaan yang mengungkapkan pertanggungjawaban sosial di atas rata-rata. Hal ini menunjukkan bahwa perusahaan yang termasuk klasifikasi high profile mengungkapkan pertanggungjawaban sosial lebih baik.

Pengaruh Ukuran Perusahaan (X1), Ukuran Dewan Komisaris (X2) dan Sensitivitas Industri (X3) Terhadap Pengungkapan Corporate Social Responsibility 
Berdasarkan hasil uji $\mathrm{F}$, diperoleh nilai probabilitas sebesar 0,004. Karena signifikan lebih kecil daripada nilai alpha 0,05 , maka model regresi dapat digunakan untuk memprediksi Probability (Y) atau dapat dikatakan bahwa Ukuran perusahaan, Ukuran Dewan Komisaris dan Sensitivitas Industri secara bersama-sama (simultan) berpengaruh terhadap pengungkapan corporate social responsibility.

Hal ini sejalan dengan penelitian yang dilakukan oleh Subiantoro (2015) yang menyimpulkan bahwa Ukuran perusahaan, Ukuran Dewan Komisaris dan Sensitivitas Industri secara bersama-sama (simultan) berpengaruh terhadap pengungkapan corporate social responsibility.

\section{KESIMPULAN DAN SARAN}

\section{Kesimpulan}

Berdasarkan pengujian hasil penelitian yang telah dilakukan terhadap judul pengaruh ukuran perusahaan, ukuran dewan komisaris dan sensitivitas industri terhadap pengungkapan corporate social responsibility pada perusahaan yang terdaftar di BEI tahun 2014-2016 maka peneliti dapat mengambil kesimpulan sebagai berikut:

1. Ukuran perusahaan berpengaruh signifikan terhadap pengungkapan corporate social responsibility pada perusahaan LQ-45 yang terdaftar di BEI tahun 2014-2016.

2. Ukuran dewan komisaris tidak berpengaruh signifikan terhadap pengungkapan corporate social responsibility pada perusahaan LQ-45 yang terdaftar di BEI tahun 2014-2016.

3. Sensitivitas industri berpengaruh signifikan terhadap pengungkapan corporate social responsibility pada perusahaan LQ-45 yang terdaftar di BEI tahun 2014-2016.

4. Ukuran perusahaan, ukuran dewan komisaris dan sensitivitas industri secara bersama-sama (simultan) berpengaruh terhadap pengungkapan corporate social responsibility.

\section{Saran}

1. Bagi anggota RUPS yang memiliki wewenang untuk mengusulkan, mengangkat dan memberhentikan dewan komisaris agar memperhatikan lagi calon- calon dewan komisaris yang akan diusulkan. Sebaiknya memilih dewan komisaris yang independen, bisa mewakili kepentingan stakeholder dan bisa menjalankan fungsi pengawasan terhadap manajemen.

2. Bagi investor hendaknya sebelum menanamkan modalnya pada perusahaan, terlebih dahulu memperhatikan laporan tahunan perusahaan yang mencantumkan tentang CSR agar mengetahui perusahaanperusahaan mana yang telah menjalankan tanggung jawab sosialnya dengan baik sehingga memperoleh legitimasi yang baik dari masyarakat.

3. Bagi peneliti agar menambah jumlah tahun pengamatan, menambah variabel bebas (independen) yang terkait dengan pengungkapan CSR, seperti kepemilikan saham asing, pertumbuhan perusahaan (growth company), praktek good corporate governance (GCG) dan beberapa faktor lain. Dan disarankan juga dapat menambah atau mengganti objek penelitian selain perusahaan LQ-45. Sehingga pengungkapan tanggung jawab sosial dapat digunakan tidak hanya pada perusahaan LQ-45.

\section{KEPUSTAKAAN}

Anggraini. Fr. R. (2006). Pengungkapan Informasi Sosial dan Faktor-faktor yang Mempengaruhi Pengungkapan Informasi Sosial dalam Laporan Keuangan Tahunan (studi empiris pada perusahaan-perusahaan yang terdaftar Bursa Efek Jakarta). Simposium Nasional Akuntansi 9.

Arifin, Zainal. (2013). Analisis Pengaruh Ukuran Perusahaan, Profitabilitas, Leverage Dan Ukuran Dewan Komisaris Terhadap Pengungkapan Tanggungjawab Sosial Perusahaan (Corporate Social Responsibility). Jurnal Al-Iqtishad Volume 9 Nomor 1.2013.

Aulia, F. Z. (2015). Pengaruh Karakteristik Perusahaan, Kinerja Lingkungan, Dan Liputan Media Terhadap Environmental Disclosure. Accounting Analysis Journal Volume 4 Nomor 3.2015.

Badjuri, Achmad. (2011). Faktor-faktor Fundamental, Mekanisme Corporate 
Governance, Pengungkapan Corporate Social Responsibility (CSR) Perusahaan Manufaktur dan Sumber Daya Alam di Indonesia. Dinamika Keuangan dan Perbankan. Journal of Accounting Volume 3 Nomor 2.2011.Hal.183-197.

Darwin, Ali. (2004). Penerapan Sustainability Reporting di Indonesia Konvensi Nasional Akuntansi V, Program Profesi Lanjutan. Yogyakarta, 13-15 Desember.

Deegan, C. (2002). Introduction the Legitimising Efect of Social and Environmental Disclosure - a Theoritical Foundation. Accounting, Auditing and Accountability Journal. Volume 15 Nomor 3. 2002.Hal.282- 311.

Djakman, Chaerul. dan N. Machmud. (2008). Pengaruh Struktur Kepemilikan terhadap Luas Pengungkapan Tanggung Jawab Sosial (CSR Disclosure) pada Laporan Tahunan Perusahaan: Studi Empiris pada Perusahaan Publik yang Tercatat di Bursa Efek Indonesia Tahun 2006. Simposium Nasional Akuntansi XI.

Djuitaningsih, Tita. (2012). Pengaruh Manajemen Laba dan Mekanisme Corporate Governance terhadap Corporate Social Responsibility Disclosure. Jurnal Fakultas Ekonomi dan Ilmu Sosial Volume 1 Nomor 2.2012.

Fahrizqi, A. (2010). Faktor-faktor yang Mempengaruhi Pengungkapan Corporate Social Responsibility (CSR) dalam Laporan Tahunan Perusahaan. Tesis S2. Universitas Diponegoro. Semarang.

Fauzi, Hasan. L. Mahoney dan A. A. Rahman. (2007). Institutional Ownership and Corporate Social Performance: Empirical Evidence from Indonesian Companies. SSRN and Issues in Social and Environmental Accounting Journal Volume 1 Nomor 2.2007.Hal.334-347.

Ghozali, Imam. (2006). Analisis Multivariate dengan Program SPSS. Badan Penerbit Universitas Diponegoro. Semarang.

Ghozali, I. dan A. Chariri. (2007). Teori Akuntansi. Badan Penerbit Universitas Diponegoro. Semarang.

Hadi, Nor. (2011). Corporate Social Responsibility. Graha Ilmu. Yogyakarta.
Hasibuan, M. R. (2001). Pengaruh Karakteristik Perusahaan Terhadap pengungkapan Sosial (Social Disclosure) Dalam Laporan Tahunan 76 Emiten di BEJ dan BES. Tesis S2. Universitas Diponegoro. Semarang.

Hoffman, Richard C. (2007). Corporate Social Responsibility In The 1920s: An Institutional Perspective. Journal of Management History Volume 3 Nomor 1.2007.Hal.55-73.

https:// www.globalreporting.org/.Global Reporting Initiative. GRI Sustainability Reporting GuideLines G4.diunduh pada 29 April 2017.

http://www.idx.co.id/idid/beranda/perusahaantercat at/profilperusahaantercatat.aspx.diunduh kamis 15 Maret 2017.

Indrawati, N. (2009). Pengungkapan Corporate Social Responsibility dalam Annual Report serta Pengaruh Political Visibility dan Economic Performance. Pekbis Jurnal Volume 1 Nomor 1.2009.Hal.111.

Michelon, Giovanna dan Parbonetti, Antonio. (2010). The Effect of Corporate Governance on Sustainability Disclosure. Springer Science \& Business Media 14 September 2010.

Mulyadi. (2002). Auditing. Jilid 1 Edisi Enam. Salemba Empat. Jakarta

Munif, A. M. (2010). Faktor-Faktor Yang Mempengaruhi Indeks Pengungkapan Corporate Social Responsibility Di Indonesia (Studi Empiris Pada Perusahaan Non Keuangan Yang Listing Di Bursa Efek Indonesia). Tesis S2. Universitas Diponegoro. Semarang.

Nur, Marzully (2012). Analisis Faktor-Faktor Yang Mempengaruhi Pengungkapan corporate social responsibility di Indonesia (Studi empiris pada perusahaan berkategori high profile yang listing di bursa efek indonesia. Jurnal Nominal Volume 1 Nomor 1.2012.Hal.1-13.

Nurkhin, Ahmad. (2009). Corporate Governance dan Profitabilitas; Pengaruhnya terhadap Pengungkapan Tanggung Jawab Sosial Perusahaan (Studi Empiris pada Perusahaan yang Terdaftar di Bursa Efek Indonesia. Jurnal Magister Akuntansi Volume 2 Nomor 1.2009. 
Oyelere, Wang. dan Song L. (2011). Determinants of Social Responsibility Disclosure By Chinese Firms. Dalam Discussion Paper University of Nothingham. Nottingham.

Palepu. Healy. (2005). Corporate Finance Five Editions. McGraw-Hill, Irwin.

Pian, A. M. (2010). Pengaruh Karakteristik Perusahaan dan Regulasi Pemerintah Terhadap Pengungkapan Corporate Social Responsibility (CSR) Pada Laporan Tahunan di Indonesia. Skripsi S1. Universitas Diponegoro. Semarang.

Purwanto, Agus. (2011). Pengaruh Tipe Industri, Ukuran Perusahaan, Profitabilitas, Terhadap Corporate Social Responsibility. Jurnal Akuntansi \& Auditing Volume 8 Nomor 1.2011.Hal.1-94.

Putra, E. N. (2011). Pengaruh Karakteristik Perusahaan Terhadap Pengungkapan Corporate Social Responsibility (Csr). Skripsi S1.Universitas Diponegoro. Semarang.

Radyati, Maria R. N. (2008). Corporate Social Responsibility untuk Pemberdayaan Ekonomi Lokal. Indonesia Busines Link. Jakarta

Ratnasari, Yunita. (2011). Pengaruh Corporate Governance Terhadap Luas Pengungkapan Tanggung Jawab Sosial Perusahaan di dalam Sustainability Report. Skripsi S1. Universitas Diponegoro. Semarang.

Rawi dan M. Muchlish. (2010). Kepemilikan Manajemen, Kepemilikan Institusi, Leverage dan Corporate Social Responsibility. Simposium Nasional Akuntansi XIII.

Republik Indonesia. (2007). Undang-Undang Nomor 40 Tahun 2007 tentang Perseroan Terbatas. Depkeu. Jakarta.

Ross W. J. (2012). Corporate Finance 9th Edition. Irwin, McGraw-Hill.

Saleh, Mustaruddin, Norhayah Zulkifli, dan Rusnah Muhamad. (2010). Corporate Social Responsibility Disclosure and Its Relation on Institutional Ownership. Managerial Auditing Journal Volume 25 Nomor 6. 2010. Hal. 591-613.

Saputra, E. S. (2016). Pengaruh Leverage, Profitabilitas Dan Size Terhadap Pengungkapan Corporate Social
Responsibility Pada Perusahaan Di Bursa Efek Indonesia. Journal of Economic and Economic Education Vol. 5 No. 1. Hal. (75-89)

Sayekti, Yosefa dan Wondabio, L. S. (2007). Pengaruh CSR Disclosure terhadap Earning Response Coefficient (Suatu Studi Empiris Pada Perusahaan yang Terdaftar di Bursa Efek Jakarta). Simposium Nasional Akuntansi X.

Sembiring, R. A. (2005). Karakteristik perusahaan dan Pengungkapan Tanggung Jawab Sosial: Studi Empiris pada Perusahaan yang Tercatat di Bursa Efek Jakarta. Simposium Nasional Akuntansi VIII.

Sembiring, E. R. (2006). Karakteristik Perusahaan dan Pengungkapan Tanggung Jawab Sosial: Study Empiris pada Perusahaan yang Tercatat di Bursa Efek Jakarta. Jurnal Maksi Volume. 6 Nomor 1.Januari.200.Hal. 69-85.

Setianingsih, Y. Pratama. (2014). Pengaruh Good Coorporate Governance Dan Pengungkapan Corporate Social Responsibility Terhadap Kinerja Perusahaan Dan Nilai Perusahaan (Studi Kasus Pada Perusahaan Manufaktur yang Terdaftar Di BEI periode 2010-2012). Jurnal S1 Akuntansi Universitas Pendidikan Ganesha Volume 2 Nomor 1. 2014

Sitepu, A. C. dan Hasan. (2009). Faktor-faktor Yang Mempengaruhi Pengungkapan Informasi Sosial Dalam Laporan Tahunan Perusahaan Manufaktur Yang Terdaftar di Bursa Efek Jakarta. Skripsi S1. Program Studi Akuntansi. Universitas Islam Indonesia. Yogyakarta.

Subiantoro, O. H. (2015). Pengaruh Karakteristik Perusahaan Terhadap Pengungkapan Corporate Social Responsibility. Jurnal Ilmu \& Riset Akuntansi Volume 4 Nomor 9.2015.Hal.1-21.

Sugiyono. (2013). Metode Penelitian Pendidikan. Alfabeta. Bandung.

Utomo, Muhammad Muslim. (2000). Praktek Pengungkapan Sosial Pada Laporan Tahunan Perusahaan di Indonesia (Studi Perbandingan Antara Perusahaan-Perusahaan High Profile dan Low Profile). Simposium Nasional Akuntansi III. Jakarta. 
Wijaya, Maria. (2012). Faktor-Faktor Yang Mempengaruhi Pengungkapan Tanggung Jawab Sosial Pada Perusahaan Manufaktur Yang Terdaftar Di Bursa Efek Indonesia. Jurnal Ilmiah Mahasiswa Akuntansi Vol 1, No. 1.

Yuliana, Rita. (2008). Pengaruh Karakteristik Perusahaan Terhadap Pengungkapan Corporate Social Responsibility (CSR) Dan Dampaknya Terhadap Reaksi Investor. Jumal Akuntansi dan Keuangan Indonesia Volume 5 Nomor 2.2008.

Zaenuddin, Achmad. (2007). Faktor-Faktor Yang Berpengaruh Terhadap Praktek Pengungkapan Sosial Dan Lingkungan Pada Perusahaan Manufaktur Go Publik. Tesis S2. Universitas Diponegoro. Semarang. 
